\title{
Analysis of Factors Affecting Gillnet Fisherman Income <10 GT at Fish Auction Place, Indramayu Regency
}

\author{
Ali Rizki Maulana ${ }^{1}$, Abdul Kohar Mudzakir ${ }^{1}$, Tita Elfitasari ${ }^{1}$ \\ Alirizkimaulana06@gmail.com \\ ${ }^{1}$ Department of Aquatic Resources, Faculty of Fisheries and Marine Sciences, Diponegoro \\ University, Indonesia
}

Received: December 4, 2020

Revised: December 20, 2020

Accepted: December 28, 2020

\begin{abstract}
The purpose of this study is to analyze the income level of gillnet fishermen <10 GT, to analyze the factors that affect the level of income, and to formulate strategies and solutions to increase income. This research was conducted at the Fish Auction Place (TPI) Pabean Udik, Pabean Udik Village, Indramayu Regency. This location was chosen because the Udik Customs Fish Auction Place (TPI) is dominated by fishermen using gillnet fishing gear who have vessels $<10 \mathrm{GT}$. The method used is the census method with samples taken as a whole. The analysis used in this research is the Logistic Regression Analysis and the SWOT Analysis. Research results obtained by using IBM SPSS, namely for the Sig Value Variable in the Equation is $100 \%$, this value is interpreted by 8 (factors) Independent variables can affect income only educational factors that do not affect income and for the results obtained from SWOT analysis namely to increase the income of gillnet fishermen <10 GT at TPI Pabean Udik, namely the development of technology and fisheries business scale, development of access to capital for fishermen, development of marketing access, development of facilities and infrastructure at TPI Pabean Udik, Development of diversification of fish management and environmentally friendly fisheries management.
\end{abstract}

Keywords: Income, Fishermen Gillnet, Indramayu

\section{Introduction}

Indramayu is one of the Regency that has the longest coastline, which is $147 \mathrm{~km}$ stretching along the north coast. Especially in Indramayu Regency, the fishing gear that is widely used is the gillnet, which is operated by fishermen according to the size of the ship used. The number of gillnet fishing gear operated in the coastal area of Indramayu Regency reaches 3253 units (Department of Fisheries and Marine, Indramayu Regency, 2016). Even though the gillnet fishing gear is classified as simple fishing gear, the gillnet fishermen are required to understand how to operate the fishing gear.

Fishermen do their work in order to earn income for the necessities of life. For its implementation, some equipment is needed and is influenced by many factors to support the success of the activity. According to Salim (1999) factors that influence fishermen's income include social and economic factors consisting of the amount of capital, the number of boats, the number of workers, the distance traveled to the sea, and experience. Thus the income of fishermen is based on the size of the catch volume, there are still several other factors that determine it, namely social and economic factors apart from the above.

The number of fish catch reflects the output or production results of a fisherman or group. Production activities describe the relationship between the amount of production output and the number of labor resources to create added value from the output referred to (Riana et al.,

Copyright (C) 2020, Journal of Asian Multicultural Research for Economy and Management Study, 75

Under the license CC BY-SA 4.0 
2014). According to Sukirno (2009) production factors also need factors, which include capital, land, technology, and of course human resources. Goldin (2014) describes Human Capital theory, namely knowledge of expertise, and health conditions that humans have also have an influence on production results. Fish production is certainly influenced by the experience of a fisherman in line with increasing experience will increase knowledge in fishing.

This statement is reinforced by research by Chowdhury et al. (2014) that a person's productivity is influenced by work experience, and work experience affects the average amount of income earned. Of course, the longer the fishermen's experience at sea will increase their expertise in catching (production) fish so that more fish are caught, and the income they receive will increase through fish sales (Mahi \& Nazara, 2012). In general, the length of time at sea determines the yield or amount of fish catch because fishermen need time or duration to catch fish. Research conducted by Krisnandhi (1969) reveals that the length of time at sea has an effect on fish production if the longer it is, the more fish catches are caught by fishermen.

According to Rahim's (2016) research, the power of the boat engine affects the amount of fish catch, fishermen who use engine boats get a higher number of catches than those who do not use an engine. This opinion is supported by Putra et al. (2017) that technology has a dominant factor that affects catch acquisition. If the fishing gear used is more modern, it will increase the catch obtained by fishermen, this will affect the income earned by fishermen in order to balance the basic needs of the fishermen community life will be more fulfilled. Research conducted by Sukiyono (2015), the greater the operational costs at sea, the greater the chances of catching the catch. According to research conducted by Lisa (2015), the amount of operational costs implies a greater total income of fishermen. Because operational costs can increase the amount of fish caught by fishermen.

The purpose of this study is to analyze the income level of gillnet fishermen $<10$ GT obtained from fishing in Indramayu waters, to analyze the factors that affect the income level of gillnet fishermen <10 GT at TPI Pabean Udik, Indramayu Regency and develop strategies and solutions to increase the income of gillnet fishermen. $<10$ GT at Fish Auction Place (TPI) Pabean Udik, Indramayu Regency.

\section{Methods}

This research was conducted at the Fish Auction Place (TPI) Pabean Udik, Pabean Udik Village, Indramayu Regency. This location was chosen because the TPI Pabean Udik was dominated by fishermen using gillnet fishing gear who had vessels $<10$ GT. The research schedule includes the preparation, implementation, and reporting of research results. Research preparation was carried out in August 2019. The study was conducted from September to November 2019. Data of fishermen who are at TPI Pabean Udik (who auctioned their catch) who use gillnet fishing gear using vessels $<10 \mathrm{GT}$. The socio-economic data of gillnet fishermen at TPI Pabean Udik uses the open interview method and the census method where according to Arikunto (2012) if the population is less than 100 people, the total sample size is taken as a whole, but if the population is greater than 100 , it can be taken 10 $15 \%$ or $20-25 \%$ of the population.

The analysis used in this study is to use Logistic Regression Analysis where according to Hosmer \& Lemeshow (2000), logistic regression is a method that can be used to find the relationship between dichotomous response variables (nominal/ordinal scale with two categories) with one or more predictor variables on a categorical or continuous scale. The logistic regression model consists of logistic regression with binary, ordinal, and multinomial

Copyright (C) 2020, Journal of Asian Multicultural Research for Economy and Management Study, Under the license CC BY-SA 4.0 
responses. Binary logistic regression is a data analysis method used to find the relationship between the response variable (y) which is binary (dichotomous) and the predictor variable (x) which is categorical or continuous and SWOT analysis is a strategic planning method used to evaluate Strengths, Weakness, Opportunities, and Threats in a project or business. This involves setting the goals of the business or project venture and identifying internal and external factors that are good and beneficial for achieving those goals. SWOT is an abbreviation of, $\mathrm{S}$ which is Strength or strength, W is Weakness or weakness, O is Opportunity or opportunity, and T is Threat or threat. This SWOT is usually used to analyze a condition where a plan will be made to carry out a work program (Buchari Alma, 2008).

\section{Results and Discussion}

Tabel 1. Karakteristik Sosial Ekonomi Nelayan

\begin{tabular}{|c|c|c|c|c|}
\hline No & \multicolumn{2}{|c|}{ Respondents Characteristics } & $\begin{array}{l}\text { Number of } \\
\text { Respondents }\end{array}$ & $\begin{array}{c}\text { Percentage } \\
(\%)\end{array}$ \\
\hline 1. & $\begin{array}{l}\text { Umur }\left(X_{1}\right) \\
\text { Depkes RI (2009) }\end{array}$ & $\begin{array}{l}\text { 1. } 12-25 \text { Years } \\
\text { 2. } 26-35 \text { Years } \\
\text { 3. } 36-45 \text { Years } \\
\text { 4. }>45 \text { Years }\end{array}$ & $\begin{array}{c}0 \\
6 \\
30 \\
48\end{array}$ & $\begin{array}{c}0 \% \\
7,14 \% \\
35,72 \% \\
57,14 \%\end{array}$ \\
\hline 2. & $\begin{array}{l}\text { Education }\left(\mathrm{X}_{2}\right) \\
\text { LAW No. } 202003\end{array}$ & $\begin{array}{l}\text { 1. Did not graduate from } \\
\text { Elementary School } \\
\text { 2. Graduated from Elementary } \\
\text { School } \\
\text { 3. Junior School-High School } \\
\text { 4. Higher Education }\end{array}$ & $\begin{array}{l}55 \\
24 \\
5 \\
0\end{array}$ & $\begin{array}{c}65,48 \% \\
28,57 \% \\
5,95 \% \\
0 \%\end{array}$ \\
\hline 3. & $\begin{array}{l}\text { Experience Becoming a } \\
\text { Fisherman }\left(X_{3}\right) \\
\text { Nababan }(2017)\end{array}$ & $\begin{array}{l}\text { 1. } 0-12,5 \text { Years } \\
\text { 2. } 12,5-25 \text { Years } \\
\text { 3. } 25-37,5 \text { Years } \\
\text { 4. } 37,5-50 \text { Years }\end{array}$ & $\begin{array}{c}3 \\
19 \\
33 \\
29\end{array}$ & $\begin{array}{c}3,57 \% \\
22,62 \% \\
39,29 \% \\
34,52 \%\end{array}$ \\
\hline 4. & Jumlah ABK $\left(\mathrm{X}_{4}\right)$ & $\begin{array}{l}\text { 1. } 1 \text { the crew } \\
\text { 2. } 2 \text { the crew } \\
\text { 3. } 3 \text { the crew } \\
\text { 4. } 4 \text { the crew }\end{array}$ & $\begin{array}{l}14 \\
41 \\
19 \\
10\end{array}$ & $\begin{array}{c}16,67 \% \\
48,81 \% \\
22,62 \% \\
11,9 \%\end{array}$ \\
\hline 5. & Capital $\left(\mathrm{X}_{5}\right)$ & $\begin{array}{l}\text { 1. } 3.000 .000 \mathrm{IDR} \\
\text { 2. } 4.000 .000 \mathrm{IDR} \\
\text { 3. } 6.000 .000 \mathrm{IDR}\end{array}$ & $\begin{array}{c}51 \\
9 \\
24\end{array}$ & $\begin{array}{l}60,71 \% \\
10,72 \% \\
28,57 \%\end{array}$ \\
\hline 6. & Ship Size $\left(\mathrm{X}_{6}\right)$ & $\begin{array}{l}\text { 1. } 2 \mathrm{GT} \\
\text { 2. } 3 \mathrm{GT} \\
\text { 3. } 4 \mathrm{GT} \\
\text { 4. } 5 \mathrm{GT}\end{array}$ & $\begin{array}{c}47 \\
11 \\
21 \\
5\end{array}$ & $\begin{array}{c}55,95 \% \\
13,09 \% \\
25 \% \\
5,95 \%\end{array}$ \\
\hline 7. & $\begin{array}{l}\text { Number of Trip per Month } \\
\left(\mathrm{X}_{7}\right)\end{array}$ & $\begin{array}{l}\text { 1. } 10-15 \text { Days } \\
\text { 2. } 16-20 \text { Days } \\
\text { 3. } 21-25 \text { Days } \\
\text { 4. > } 25 \text { Days }\end{array}$ & $\begin{array}{c}0 \\
0 \\
74 \\
10\end{array}$ & $\begin{array}{c}0 \% \\
0 \% \\
88,10 \% \\
11,90 \%\end{array}$ \\
\hline 8. & Number of Net Used (Piss) & $\begin{array}{ll}\text { 1. } & 20 \text { Pieces } \\
\text { 2. } & 30 \text { Pieces } \\
\text { 3. } & 40 \text { Pieces } \\
\text { 4. } & 50 \text { Pieces }\end{array}$ & $\begin{array}{c}47 \\
11 \\
21 \\
5\end{array}$ & $\begin{array}{c}55,95 \% \\
13,09 \% \\
25 \% \\
5,95 \%\end{array}$ \\
\hline
\end{tabular}

Age

Most of the respondents were elderly (over 45 years), as many as 48 people (57.14\%). A total of 0 people $(0 \%)$ aged 25 years and under. A total of $7.14 \%$ or 6 people were early adults (26 - 35 years) and $35.72 \%$ were late adults ( 36 - 45 years) as many as 30 people.

Copyright (C 2020, Journal of Asian Multicultural Research for Economy and Management Study, Under the license CC BY-SA 4.0 
This is in line with research conducted by Prihandoko et al. (2012) which states that the average fisherman on the North Coast of West Java Province is in the range of 46.4 years. This situation is not much different from the research results of Muflikhati et al. (2010) which states that the average age of fishermen on the North Coast and South Coast of West Java is in the range of 43.1 years.

\section{Education}

Fishermen who land their catch at the Fish Auction Place (TPI) Pabean Udik Indramayu have a low level of education where 55 respondents or $65.48 \%$ of education do not pass elementary school (SD) due to various reasons why fishermen do not pass SD because they have been taught from a young age since childhood, he has been doing fishing activities in the sea. Some respondents have an education level that has passed elementary school (SD), namely 5 respondents or $5.95 \%$. In some research literature, fishermen's education level is generally low. In the research of Muflikhati et al. (2010), Adriyani (2000) and Prihandoko et al. (2012) stated that the average fishermen on the north coast of West Java had only 4.63 years of formal education, meaning they did not reach grade 5 Elementary School (they did not pass Elementary School).

\section{Experience Becoming a Fisherman}

The respondents interviewed had relatively long experience as fishermen. A total of 33 respondents or 39.29\% have experienced being fishermen for 25 - 37.5 years. Then 29 respondents or $34.52 \%$ have experienced 37.5 - 50 years. Then as many as 19 respondents or $22.62 \%$ experienced being fishermen for $12.5-25$ years. And only 3 respondents or $3.57 \%$ had experience as fishermen for 0-12.5 years.

\section{Number of Ship Crew (ABK) on board}

The number of crew onboard the ship is one of the most important things in fishing activities where the function of the crew itself is to assist in the operation of fishing gear. In this case, each respondent when carrying out fishing activities does not escape to bring the crew to operate their fishing gear. A total of 41 respondents or $48.81 \%$ when going to sea with 2 crew members, then 19 respondents or $22.62 \%$ carrying 3 crew members, 14 respondents or $16.67 \%$ carrying 1 ship crew and the last one with 4 ship crews as many as 10 respondents or $11.9 \%$.

\section{Capital}

Respondents who were interviewed when they wanted to carry out fishing activities spent most of the capital within a month. The fishermen spent 3,000,000 IDR as many as 51 respondents or $60.71 \%$ while the fishermen who spent $4,000,000$ IDR as many as 9 respondents or $10.72 \%$ and the last is fishermen who spend 6,000,000 IDR a month as many as 24 respondents or $28.57 \%$. Ship Size (GT). The size of the boats used by fishermen at the Shrimp Customs Fishing Landing (PPI) ranges from 2 - 5 GT. Including small fishermen. As for the spread, the largest number of respondents using a 2 GT ship was 47 fishermen or $55.95 \%$. Then for $3 \mathrm{GT}$ as many as 11 fishermen or $13.09 \%$, then for respondents who used 4 GT ships were 21 fishermen or $25 \%$ and lastly, respondents who used ships using 5 GT ships were 5 fishermen or $5.95 \%$.

\section{Number of Trips Per Month}

The number of trips is the number of fishing activities that are accumulated in a month. As for respondents who carried out fishing activities in a month as many as 21-25 days a month were 74 fishermen or $88.10 \%$ and the remaining 10 fishermen or $11.90 \%$ carried out fishing activities for more than 25 days.

Copyright (C) 2020, Journal of Asian Multicultural Research for Economy and Management Study, Under the license CC BY-SA 4.0 


\section{Number of nets used (pieces)}

The number of nets used by fishermen at the Shrimp Customs Fishing Landing (PPI) ranges from 20 Piss - 50 Piss. The spread is for the largest respondents using 20 Piss nets as many as 47 fishermen or $55.95 \%$. Then for 30 Piss as many as 11 fishermen or $13.09 \%$, then for respondents who used 40 Piss ships were 21 fishermen or $25 \%$ and lastly, respondents who used boats using 50 Piss were 5 fishermen or $5.95 \%$.

\section{Binary Logistic Regression Analysis}

In Hosmer \& Lemeshow (2000) Test table, the sig value is .916 or $91.6 \%$. This means that data regarding the socio-economic characteristics of gillnet fishermen $<10 \mathrm{GT}$ at TPI Pabean Udik to influence income levels can be analyzed using logistic regression.

Table 2. Value of the Hosmer \& Lemeshow Test

\begin{tabular}{|c|c|c|c|}
\hline \multicolumn{4}{|c|}{ Hosmer and Lemeshow Test } \\
\hline Step & Chi-square & df & Sig. \\
\hline 1 & 2.647 & 7 & .916 \\
\hline
\end{tabular}

In the table of variables in the equation, the value of the age variable has a sig value of 0.11 . The education variable has a sig value of 0.723 . The experience variable has a sig value of 0.013 . The variable number of crew members has a sig value of 0.239 . The trip variable that is followed has a sig value of 0.260 . The capital variable has a sig value of 0.019 . The ship size variable has a sig value of 0.009 . The variable number of nets (piss) has a sig value of 0.213 .

Table 3.Variable values in the equation

\begin{tabular}{|c|c|c|c|c|c|c|c|}
\hline & B & S.E. & Wald & df & Sig. & $\operatorname{Exp}(B)$ \\
\hline \multirow{9}{*}{$\begin{array}{l}\text { Ste } \\
\mathrm{p} \\
1^{\mathrm{a}}\end{array}$} & Age & 3.375 & 1.331 & 6.433 & 1 & .011 & 29.231 \\
\hline & Education & -.333 & .940 & .125 & 1 & .723 & .717 \\
\hline & Experience & 2.750 & 1.113 & 6.107 & 1 & .013 & 15.649 \\
\hline & Crew & 3.578 & 3.037 & 1.388 & 1 & .239 & 35.790 \\
\hline & Trip & 3.266 & 2.896 & 1.271 & 1 & .260 & 26.198 \\
\hline & Capital & 3.377 & 1.434 & 5.546 & 1 & .019 & 29.295 \\
\hline & Ship Size & -6.878 & 2.615 & 6.918 & 1 & .009 & .001 \\
\hline & $\begin{array}{l}\text { Number of Net } \\
\text { (Pieces) }\end{array}$ & 2.462 & 1.977 & 1.551 & 1 & .213 & 11.732 \\
\hline & Constant & -65.150 & 2.687 & 9.756 & 1 & .002 & .000 \\
\hline
\end{tabular}

With a confidence level of $95 \%$, it can be concluded that the eight socio-economic variables significantly affect the income level of Gillnet fishermen <10 GT at TPI Pabean Udik, Pabean Udik Village, Indramayu Regency, only the educational factor has no effect on income.

\section{SWOT Analysis}

The preparation of this SWOT analysis was carried out after receiving or receiving input from various parties, including through focus group discussions (FGD), questionnaires for fishing communities and deep interviews with key figures as well as through existing literature reviews.

\section{Strength}

Has a large number of small fishermen (S1); There is strong support from fishing communities, fishing community organizations and the Indramayu Regency Government to develop the Fisheries and Marine sector, especially for Small Fishermen (S2); Number of

Copyright (C) 2020, Journal of Asian Multicultural Research for Economy and Management Study, 
fishermen who are old so they have more experience (S3); and Persistence/motivation of fishermen (S4).

\section{Weakness}

Fishery business technology is still simple (W1); Weak fishermen in terms of capital (W2); Limited Access Marketing (W3); and Limited fishery business support facilities (W4).

\section{Opportunity}

Has a very good potential for capture fisheries resources to be developed (O1); The geographical position of Indramayu Regency which is very strategic and profitable because it is surrounded by oceans (O2); Has excellent coastal areas and small islands (O3); and a very conducive atmosphere around the TPI Pabean Udik Indramayu Regency (O4).

\section{Threat}

The threat of environmental degradation due to global climate change as well as threatening fishery product production and food security (T1); The practice of fishing by methods and using destructive fishing gear in the waters of Indramayu (T2); Low Fish Prices (T3); and Changing and unpredictable weather patterns and seasons (T4).

\section{Assessment of Internal and External Factors}

To measure the influence of internal and external factors on fisheries business in order to improve the empowerment of coastal communities, the internal factors analysis summary (IFAS) matrix model and the external factor analysis summary (EFAS) matrix are used. Based on the IFAS analysis, the total value of internal factors obtained is 2.77 , which is greater than 2.5 which is the average value. This illustrates that the internal condition of fishermen at TPI Pabean Udik can actually solve various internal problems in the fishery fisheries business (Table 14). The results of IFAS calculations show that the internal factors that have the main strength to increase fishermen's income are (1) having a large number of small fishermen (0.68); (2) There is strong support from the fishing community, fishing community organizations, and the Indramayu Regency Government (0.48); (3) Persistence and Motivation of Fishermen (0.42); (4) The number of fishermen who are mature has a lot of experience (0.39). While the main weaknesses in increasing fishermen's income, namely: (1) fishery business technology are still simple (0.32); (2) Weak fishermen in terms of capital (0.18); (3) Limited marketing access (0.16), and (4) limited fishery supporting infrastructure $(0.14)$.

Table 4. Assessment of Internal Factor Analysis Summary

\begin{tabular}{|l|c|c|c|}
\hline Internal Factors & Weight & Rating & Score \\
\hline Strengths & & & \\
\hline Has a large number of small fishermen (S1) & 0,17 & 4 & 0,68 \\
\hline $\begin{array}{l}\text { There is strong support from fishing communities, fishing } \\
\text { community organizations (S2) }\end{array}$ & 0,16 & 3 & 0,48 \\
\hline Persistence and Motivation of Fishermen (S3) & 0,14 & 3 & 0,42 \\
\hline Number of fishermen who are mature with a lot of experience (S4) & 0,13 & 3 & 0,39 \\
\hline$\quad$ Total Strength & & & $\mathbf{1 , 9 7}$ \\
\hline Weakness & & & \\
\hline Fishery business technology is still simple (W1) & 0,16 & 2 & 0,32 \\
\hline Weak fishermen in terms of capital (W2) & 0,09 & 2 & 0,18 \\
\hline Limited Access Marketing (W3) & 0,08 & 2 & 0,16 \\
\hline Limited fisheries business support facilities (W4) & 0,07 & 2 & 0,14 \\
\hline$\quad$ Total Weakness & & & $\mathbf{0 , 8}$ \\
\hline
\end{tabular}




\begin{tabular}{ll|l|l|l|}
\hline \multicolumn{2}{|c|}{ Total Internal Factor } & $\mathbf{1}$ & $\mathbf{2 , 7 7}$ \\
\hline Note: & $1=$ Very Weak & $2=$ Weak & & \\
& $3=$ Pretty Strong & $4=$ Very Strong
\end{tabular}

Table 5. Assessment of External Factor Analysis Summary

\begin{tabular}{|l|c|c|c|}
\hline External Factors & Weight & Rating & Score \\
\hline Opportunities & & & \\
\hline $\begin{array}{l}\text { Has the potential to capture fisheries resources which are } \\
\text { very good to be developed (O1) }\end{array}$ & 0,18 & 4 & 0,72 \\
\hline Opportunities for employment in fisheries (O2) & 0,16 & 3 & 0,48 \\
\hline Local government policy support (O3) $\quad 0,15$ & 3 & 0,45 \\
\hline Has excellent coastal Strength & 0,13 & 3 & 0,39 \\
\hline \multicolumn{1}{|c|}{ Theas and small islands (O4) } & & & $\mathbf{2 , 0 4}$ \\
\hline Threats & & 3 & 0,39 \\
\hline $\begin{array}{l}\text { The threat of environmental degradation due to global } \\
\text { climate change and at the same time threatens fishery } \\
\text { product production and food security (T1) }\end{array}$ & 0,13 & 3 & 0,3 \\
\hline $\begin{array}{l}\text { The existence of fishing practices using methods that damage } \\
\text { the environment in the waters of Indramayu (T2) }\end{array}$ & 0,1 & 3 & 0,16 \\
\hline Low Fish Prices (T3) & 0,08 & 2 & 0,14 \\
\hline $\begin{array}{l}\text { Changing and unpredictable weather patterns and seasons } \\
\text { (T4) }\end{array}$ & 0,07 & 2 & $\mathbf{0 , 9 6}$ \\
\hline \multicolumn{1}{|c|}{ Total Internal Factor } & $\mathbf{1}$ & & $\mathbf{3}$ \\
\hline
\end{tabular}

For external factors, the total value obtained is 3.00, which is greater than 2.5. gives an understanding that the condition of Indramayu waters is able to provide a positive response to the income of gillnet fishermen. The existing opportunities can be exploited by minimizing existing threats. The results of the EFAS table analysis show that the main external factors affecting income strategy are: (1) It has a very good potential for capture fisheries resources to be developed (0.72); (2) Geographical location of Indramayu Regency which has calm seas (0.48); (3) It has excellent coastal areas and small islands (0.45); and (4) a conducive atmosphere around the TPI Pabean Udik Indramayu Regency (0.39). Meanwhile, the main threats are: (1) The threat of environmental degradation due to global climate change and at the same time threatening fishery product production and food security $(0.39)$; (2) There is fishing practice using methods that destroy the environment in the waters of Indramayu (0.3); (3) low fish prices (0.16); and (4 Changing and unpredictable weather patterns and seasons (0.14).

Table 8. SWOT Matrix for Increased Income of Gillnet Fishermen $<10 \mathrm{GT}$ at TPI Pabean Udik, Indramayu Regency

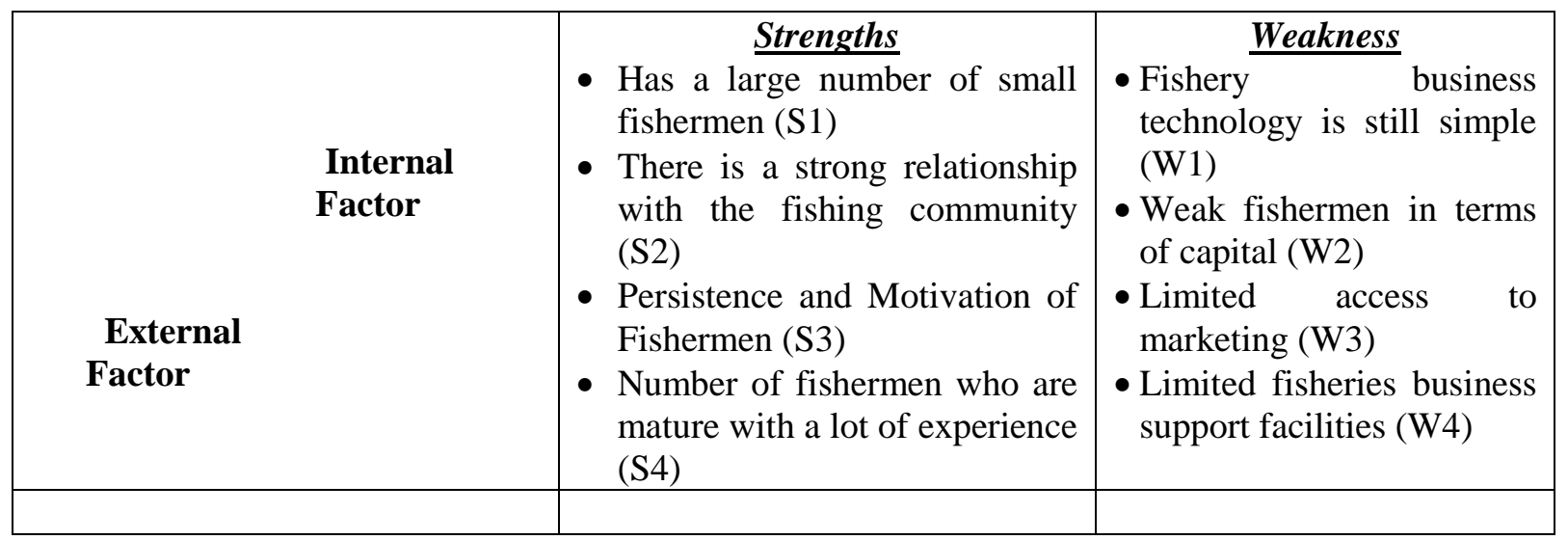

Copyright (C) 2020, Journal of Asian Multicultural Research for Economy and Management Study, Under the license CC BY-SA 4.0 


\begin{tabular}{|c|c|c|}
\hline $\begin{array}{l}\text { Opportunity } \\
\text { - Has the potential to capture } \\
\text { fisheries resources which are } \\
\text { very good to be developed } \\
\text { (O1) } \\
\text { - Opportunities for employment } \\
\text { in fisheries (O2) } \\
\text { - Local government policy } \\
\text { support (O3) } \\
\text { - Has excellent coastal areas and } \\
\text { small islands (O4) }\end{array}$ & $\begin{array}{l}\text { SO Strategy: } \\
\text { Development of technology } \\
\text { and scale of fisheries business } \\
\text { (S1 to } \mathrm{S} 4, \mathrm{O} 1 \text { to } \mathrm{O} 4 \text { ) }\end{array}$ & $\begin{array}{ll}\text { - } & \text { Pengembangan akses } \\
\text { permodalan }(\mathrm{W} 2, \mathrm{O} 3) \\
\text { - } & \text { Pengembangan akses } \\
\text { pemasaran }(\mathrm{W} 3, \mathrm{O} 3) \\
\text { - } \\
\text { Pembangunan sarana dan } \\
\text { prasarana penunjang } \\
\text { usaha perikanan }(\mathrm{W} 4, \mathrm{O} 3)\end{array}$ \\
\hline $\begin{array}{l}\text { Threats } \\
\text { - The threat of environmental } \\
\text { degradation due to global } \\
\text { climate change and at the same } \\
\text { time threatens fishery product } \\
\text { production and food security } \\
\text { (T1) } \\
\text { - The existence of fishing } \\
\text { practices using methods that } \\
\text { damage the environment in the } \\
\text { waters of Indramayu (T2) } \\
\text { - Low Fish Prices (T3) } \\
\text { - Changing and unpredictable } \\
\text { weather patterns and seasons } \\
\text { (T4) }\end{array}$ & \begin{tabular}{l}
\multicolumn{1}{c}{ ST Strategy: } \\
Development of fish processing \\
diversification $(\mathrm{S} 3, \mathrm{~T} 3)$
\end{tabular} & $\begin{array}{l}\text { WT Strategy: } \\
\text { Management of fisheries } \\
\text { resources based on } \\
\text { environmentally friendly } \\
(\mathrm{W} 1, \mathrm{~T} 2)\end{array}$ \\
\hline
\end{tabular}

\section{Conclusion}

The income level of gillnet fishermen $<10$ GT at TPI Pabean Udik is still low because the fish obtained are not too many and also most of the gillnet fishermen $<10$ GT are already dependent on middlemen, therefore some of the catch is even partly sold. to middlemen at a low price. The factors that affect the income of gillnet fishermen $<10 \mathrm{GT}$, namely from the 8 existing factors, only the education factor does not affect income and the remaining 7 other factors affect income and the strategies and solutions provided for this research are technology development and fishery business scale, development of access to capital for fishermen, development of marketing access, development of facilities and infrastructure at the Udik Customs Farm, Development of diversification of fish management and fisheries management based on environmentally friendly.

\section{References}

Chowdhury, S., Schulz, E., Milner, M., \& Van De Voort, D. (2014). Core employee based human capital and revenue productivity in small firms: An empirical investigation. Journal of Business Research, 67(11), 2473-2479.

Department of Fisheries and Marine, Indramayu Regency. (2016). Laporan Tahunan Dinas Perikanan dan Kelautan Kabupaten Indramayu Tahun 2016. Indramayu.

Goldin, C. 2016. Human Capital. National Bureau of Economic Research. Handbook of Cliometrics

Hosmer, D. W., \& Lemeshow, S. (2000). Applied Logistic Regression, John Wiley \& Sons. New York. 
Krisnandhi, S. (1969). The economic development of Indonesia's sea fishing industry. Bulletin of Indonesian Economic Studies, 5(1), 49-72.

Lisa, A. (2015). Analisa Faktor-Faktor yang Mempengaruhi Pendapatan Nelayan di Kelurahan Lumpir Kabupaten Gresik, Jawa Timur, Surabaya. Jurnal Global Ekonomi Pembangunan. 1(1).

Mahi, B. R., \& Nazara, S. (2012). Survey of recent developments. Bulletin of Indonesian Economic Studies, 48(1), 7-31.

Putra, M. G., Setiawina, N. D., \& Yasa, I. G. W. M. (2017). Analisis Pegaruh Faktor Produksi, Sosial Demografi, dan Modal Sosial terhadap Produktivitas dan Kesejahteraan Rumah Tangga Nelayan di Kabupaten Tabanan. E-Jurnal Ekonomi dan Bisnis Universitas Udayana, 165370.

Rahim, A. (2016). Komparasi hasil tangkapan nelayan tradisional wilayah pesisir pantai barat Kabupaten Barru. Jurnal Kebijakan Sosial Ekonomi Kelautan dan Perikanan, 3(2), 107-115.

Riana, I. G., Wiagustini, N. L. P., \& Meydianawathi, L. G. (2014). Master Plan UMKM berbasis perikanan untuk meningkatkan pengolahan produk ikan yang memiliki nilai tambah tinggi. Jurnal Ekonomi Kuantitatif Terapan.

Salim, A. (1999). Analisis Tingkat Pendapatan Nelayan dan Faktor-Faktor yang mempengaruhinya di Kecamatan Syiah Kuala Kotamadya Banda Aceh (Doctoral dissertation, Tesis S2 PPS Usu, Medan).

Sukirno, S. (2003). Pengantar teori mikroekonomi (edisi ketiga). Grafindo. Jakarta.

Sukiyono, K. (2015). Allocative Efficiency of Production Inputs in Capure Fishery Business in Bengkulu City: Case Study of Fishing Vessel with Gillnet Fishing Gears: Bengkulu University. Bulletin of Indonesian Economic Studies, 11(2), 99-104. 